\title{
Antimicrobial Resistance of Salmonella enteritidis and Salmonella typhimurium Isolated from Laying Hens, Table Eggs, and Humans with Respect to Antimicrobial Activity of Biosynthesized Silver Nanoparticles
}

\author{
Rasha M. M. Abou Elez ${ }^{1}$, Ibrahim Elsohaby ${ }^{2,3,4, * \mathbb{D}}$, Nashwa El-Gazzar ${ }^{5} \mathbb{D}$, Hala M. N. Tolba ${ }^{6}$, \\ Eman N. Abdelfatah ${ }^{7}$, Samah S. Abdellatif ${ }^{7}$, Ahmed Atef Mesalam ${ }^{8, *}$ (D) and Asmaa B. M. B. Tahoun ${ }^{7}$
}

check for

updates

Citation: Abou Elez, R.M.M.; Elsohaby, I.; El-Gazzar, N.; Tolba, H.M.M.; Abdelfatah, E.N.; Abdellatif, S.S.; Mesalam, A.A.; Tahoun, A.B.M.B Antimicrobial Resistance of Salmonella enteritidis and Salmonella typhimurium Isolated from Laying Hens, Table Eggs, and Humans with Respect to Antimicrobial Activity of Biosynthesized Silver Nanoparticles. Animals 2021, 11, 3554. https:// doi.org/10.3390/ani11123554

Academic Editors: Antonio Gonzalez-Bulnes and Nesreen Hashem

Received: 1 November 2021 Accepted: 10 December 2021 Published: 14 December 2021

Publisher's Note: MDPI stays neutral with regard to jurisdictional claims in published maps and institutional affiliations.

Copyright: (c) 2021 by the authors. Licensee MDPI, Basel, Switzerland. This article is an open access article distributed under the terms and conditions of the Creative Commons Attribution (CC BY) license (https:/ / creativecommons.org/licenses/by/ $4.0 /)$.
1 Department of Zoonoses, Faculty of Veterinary Medicine, Zagazig University, Zagazig 44511, Egypt; rmmohamed@zu.edu.eg

2 Department of Animal Medicine, Faculty of Veterinary Medicine, Zagazig University, Zagazig 44511, Egypt

3 Department of Health Management, Atlantic Veterinary College, University of Prince Edward Island, Charlottetown, PE C1A 4P3, Canada

4 Department of Infectious Diseases and Public Health, Jockey Club of Veterinary Medicine and Life Sciences, City University of Hong Kong, Kowloon, Hong Kong

5 Department of Botany and Microbiology, Faculty of Science, Zagazig University, Zagazig 44519, Egypt; ns_elgsazzar@zu.edu.eg

6 Department of Avian and Rabbit Medicine, Faculty of Veterinary Medicine, Zagazig University, Zagazig 44511, Egypt; halanabil85@gmail.com

7 Department of Food Control, Faculty of Veterinary Medicine, Zagazig University, Zagazig 44511, Egypt; Enabil@vet.zu.edu.eg (E.N.A.); SSAbdelfattah@vet.zu.edu.eg (S.S.A.); abbadr@vet.zu.edu.eg (A.B.M.B.T.)

8 Department of Therapeutic Chemistry, National Research Centre (NRC), Dokki, Cairo 12622, Egypt

* Correspondence: ielsohaby@upei.ca (I.E.); Ahmedatefmesalam@hotmail.com or am.mesalam@nrc.sci.eg (A.A.M.)

Simple Summary: Salmonella enterica are common foodborne pathogens that cause gastrointestinal signs in a wide range of unrelated host species including poultry and humans. The overuse of antibiotics as therapeutic agents and growth promoters in the poultry industry has led to the emergence of multidrug-resistant (MDR) microorganisms. Thus, there is a need to find alternatives to conventional antibiotics. Recently, the biosynthesized silver nanoparticles (AgNPs) have shown an excellent antimicrobial activity. In this study, we investigated the antibacterial, antivirulent, and antiresistant activities of the biosynthesized AgNPs on the MDR and virulent S. enteritidis and S. typhimurium isolated from laying hens, table eggs, and humans. The obtained results indicated that AgNPs have the potential to be effective antimicrobial agents against MDR S. enteritidis and S. typhimurium and could be recommended for use in laying hen farms.

Abstract: Salmonella enterica is one of the most common causes of foodborne illness worldwide. Contaminated poultry products, especially meat and eggs are the main sources of human salmonellosis. Thus, the aim of the present study was to determine prevalence, antimicrobial resistance profiles, virulence, and resistance genes of Salmonella Enteritidis (S. enteritidis) and Salmonella Typhimurium (S. Typhimurium) isolated from laying hens, table eggs, and humans, in Sharkia Governorate, Egypt. The antimicrobial activity of Biosynthesized Silver Nanoparticles (AgNPs) was also evaluated. Salmonella spp. were found in $19.3 \%$ of tested samples with laying hens having the highest isolation rate $(33.1 \%)$. S. Enteritidis) (5.8\%), and S. Typhimurium (2.8\%) were the dominant serotypes. All isolates were ampicillin resistant $(100 \%)$; however, none of the isolates were meropenem resistant. Multidrug-resistant (MDR) was detected in $83.8 \%$ of the isolates with a multiple antibiotic resistance index of 0.21 to 0.57 . Most isolates $(81.1 \%$ ) had at least three virulence genes ( $\operatorname{sop} B$, stn, and hilA) and none of the isolates harbored the pefA gene; four resistance genes (blaTEM, tet $A, n f_{s} A$, and $n f_{s} B$ ) were detected in $56.8 \%$ of the examined isolates. The AgNPs biosynthesized by Aspergillus niveus exhibit an absorption peak at $420 \mathrm{~nm}$ with an average size of $27 \mathrm{~nm}$. AgNPs had a minimum inhibitory concentration of $5 \mu \mathrm{g} / \mathrm{mL}$ against $S$. enteritidis and S. typhimurium isolates and a minimum bactericidal 
concentration of 6 and $8 \mu \mathrm{g} / \mathrm{mL}$ against $S$. enteritidis and S. typhimurium isolates, respectively. The bacterial growth and gene expression of $S$. enteritidis and $S$. typhimurium isolates treated with AgNPs were gradually decreased as storage time was increased. In conclusion, this study indicates that $S$. enteritidis and S. typhimurium isolated from laying hens, table eggs, and humans exhibits resistance to multiple antimicrobial classes. The biosynthesized AgNPs showed potential antimicrobial activity against MDR S. enteritidis and S. typhimurium isolates. However, studies to assess the antimicrobial effectiveness of the biosynthesized AgNPs in laying hen farms are warranted.

Keywords: Salmonella; antimicrobial agents; virulence genes; resistance genes; silver nanoparticles; expression

\section{Introduction}

Salmonella enterica are common foodborne pathogens, causing 93.8 million cases of gastroenteritis and 155,000 deaths worldwide and severe economic losses [1]. Salmonella Enteritidis (S. enteritidis) and Salmonella Typhimurium (S. typhimurium) are the dominant nontyphoidal serovars that cause mild gastrointestinal signs in a wide range of unrelated host species and severe infections in infants, the elderly, and immunocompromised individuals [2]. Nontyphoidal human salmonellosis is mostly associated with the ingestion of contaminated poultry meats and raw eggs [3]. However, table eggs get contaminated with Salmonella via horizontal transmission from the feces of infected laying hens, vertical transmission through the yolk, albumen, or eggshell membranes before oviposition and contamination of the eggshell after oviposition by infected environmental dusts [4].

Antibiotics have been extensively used in developing countries as therapeutic agents and growth promoters in laying hen farms as well as treatment for various human diseases, resulting in the emergence of antimicrobial resistance bacteria [5]. Antibiotic-resistant bacteria can be transmitted to humans either directly through the food chain or indirectly by transferring their antimicrobial resistance genes to human pathogens by mobile genetic elements associated with conjugative plasmids [6]. The presence of various virulence genes in the chromosome and plasmids of Salmonella plays a role in the pathogenesis of such bacteria inside the host [7]. Salmonella outer proteins (sops) and hilA virulence genes contribute to the invasion of host epithelial cells [8]. However, the plasmid-encoded fimbriae (pefA) gene is mediated through the adherence of Salmonella to intestinal epithelial cells [9], whereas the enterotoxin (stn) gene is responsible for enterotoxin production and diarrhea in the host [8]. Salmonella plasmid virulence (spus) has relevance to Salmonella survival and replication inside the host [10]. Therefore, understanding the antibiotic resistance mechanisms will assist in the control and reduction in the spread of resistant bacteria. Furthermore, assessing the distribution of resistance genes in bacterial populations is an additional tool to understand the antimicrobial resistance epidemiology [11]. Thus, the development of an alternatives natural antimicrobial agent is needed.

Nanoparticles are one of the alternatives that could be used as antimicrobial agents in humans and animals [12]. Silver nanoparticles (AgNPs) are among the nanoparticles that have been used for many years in different applications including wound treatment. AgNPs physical, chemical, and biological properties depend on their size and shape [13]. AgNPs have good antimicrobial activity against bacteria, fungi, and viruses, with low cytotoxicity to mammalian cells due to their nanoscale size and various shapes [14]. The mechanism behind AgNPs's actions includes their induction of cell death through generation of reactive oxygen species [15]. Furthermore, there are different factors that make AgNPs suitable for use as antimicrobial: (1) It is simple and safe to synthesize on a large scale with low cost [16]; (2) bacterial resistance to AgNPs is extremely rare; and (3) the surface of AgNPs can be easily modified and synthesized in various shapes [17]. Several studies have reported that AgNPs have antimicrobial activity against a variety of pathogens, including Salmonella 
enterica, E. coli O157:H7, Pseudomonas aeruginosa, Listeria monocytogenes, Klebsiella pneumoniae [18], and mastitis pathogens [19].

This study aimed to (1) determine the prevalence of Salmonella spp. in laying hens, table eggs, and humans, in Sharkia Governorate, Egypt; (2) detect the antimicrobial resistance profiles and virulence and resistance genes of S. enteritidis and S. typhimurium isolates; and (3) prepare and assess the antibacterial, antivirulent, and antiresistant activities of AgNPs biosynthesized by Aspergillus niveus (A. niveus) on the MDR and virulent S. enteritidis and S. typhimurium isolates.

\section{Materials and Methods}

\subsection{Sample Collection}

A total of 431 samples were collected from laying hen farms, egg retailers, and outpatient clinics in Sharkia Governorate, Egypt, between August 2019 and January 2020. Samples included 166 fecal swabs from laying hens, 165 table eggs, and 100 human stool samples. Aseptic techniques were strictly maintained during sample collection. Table eggs were individually packed in separate sterile plastic bags from egg retailers and brought to the laboratory. All human participants provided verbal or written consent to join the study.

\subsection{Salmonella spp. Isolation}

Salmonella was isolated from eggs and fecal samples as previously described Im, et al. [20], Yang, et al. [21]. The collected eggs were disinfected with 75\% alcohol, the shell was removed and the yolks and whites were mixed. A $25 \mathrm{~mL}$ of the sample was added to $225 \mathrm{~mL}$ of sterile buffered peptone water (BPW; Oxoid, Basingstoke, Hampshire, $\mathrm{UK}$ ) and then incubated at $37^{\circ} \mathrm{C}$ for $24 \mathrm{~h}$. A $100 \mu \mathrm{L}$ of incubated BPW suspension was selectively enriched in $10 \mathrm{~mL}$ of Rappaport-Vassiliadis medium (Difco, Detroit, MI, USA) and incubated at $42{ }^{\circ} \mathrm{C}$ for $24 \mathrm{~h}$. A loopful $(10 \mu \mathrm{L})$ of enriched Rappaport-Vassiliadis medium was plated onto xylose lysine deoxycholate agar (Difco, Detroit, MI, USA) and incubated at $37^{\circ} \mathrm{C}$ for $24 \mathrm{~h}$. The suspected Salmonella isolates were kept frozen at $-80^{\circ} \mathrm{C}$ in brain-heart infusion broth (Oxoid, Basingstoke, Hampshire, UK) supplemented with $15 \%$ glycerin (Synth ${ }^{\circledR}$, São Paulo, Brazil). The presumptive colonies were picked up for purification on tryptone soya agar (Oxoid, Basingstoke, Hampshire, UK) and subjected to biotyping [22] and serotyping according to the Kauffmann-White scheme [23] to determine flagellar $(\mathrm{H})$ and somatic $(\mathrm{O})$ antigens using Salmonella antiserum (Denka Seiken, Tokyo, Japan).

\subsection{Molecular Identification of Salmonella spp.}

The extracted DNA was examined by PCR targeting inv $A$ gene using the QIAamp DNA Mini Kit (Qiagen, Hilden, Germany) according to the manufacturer's guidelines [24]. Isolates identified as Salmonella spp. were subjected to identification of sefA gene (310 bp) for S. enteritidis [25] and STM4495 gene (915 bp) for S. typhimurium [26]. PCR-confirmed S. enteritidis and S. Typhimurium isolates were screened to detect $\operatorname{sop} B$ [8], stn [9], pefA [9], spvC [8], and hilA [21] virulence genes. S. typhimurium ATCC 14028 and S. enteritidis ATCC 13076 were used as positive controls. However, Escherichia coli ATCC 25922 was used as a negative control. The positive and negative controls were donated by the Biotechnology Unit, Reference Laboratory for Veterinary Quality Control on Poultry Production, Animal Health Research Institute, Dokki, Giza, Egypt, and were run alongside the tested isolates.

\subsection{Antimicrobial Susceptibility Test}

Antimicrobial resistance of $S$. enteritidis and S. typhimurium isolates was determined using the Kirby-Bauer disk diffusion method on Mueller-Hinton Agar (MHA) (Oxoid, Hampshire, UK), in accordance with the guidelines of the Clinical and Laboratory Standards Institute [27]. The antibiotic disks used in this study were ampicillin (AMP, $10 \mu \mathrm{g}$ ), ampicillin/sulbactam (SAM, $20 \mu \mathrm{g}$ ), amoxicillin-clavulanate (AMC, $30 \mu \mathrm{g}$ ), cefotaxime (CTX, $30 \mu \mathrm{g}$ ), imipenem (IPM, $10 \mu \mathrm{g})$, gentamicin (GEN, $10 \mu \mathrm{g})$, tetracycline (TET, $30 \mu \mathrm{g}$ ), ciprofloxacin (CIP, $5 \mu \mathrm{g}$ ), nalidixic acid (NAL, $30 \mu \mathrm{g}$ ), trimethoprim-sulfamethoxazole (SXT, 
$25 \mu \mathrm{g}$ ), chloramphenicol (CHL, $30 \mu \mathrm{g})$, azithromycin (AZM, $15 \mu \mathrm{g}$ ), nitrofurantoin (NIT, $30 \mu \mathrm{g})$, and meropenem (MEM, $10 \mu \mathrm{g}$ ). The zone of inhibition, measured and compared with the world standards [27], was reported as resistant (R), intermediate (I), and sensitive (S). Isolates resistant to $\geq 3$ different antimicrobial classes were considered MDR [28]. For all isolates, the multiple antibiotic resistance (MAR) index was determined using the formula: $a / b$ (where " $a$ " is the number of antimicrobial agents to which an isolate was resistant and " $b$ " is the total number of antimicrobial agents tested) following the protocol designated by Krumperman [29].

S. enteritidis and S. typhimurium isolates with phenotypic resistance to specific antimicrobial agents were selected and tested for the presence of relevant resistance genes using PCR. The targeted genes included $\beta$-lactams (blaTEM) [30], tetracyclines (tet $A$ and tet $B)[31,32]$, and nitrofurans ( $n f_{s} A$ and $\left.n f s B\right)$ [33].

\subsection{Biosynthesis and Characterization of AgNPs}

The AgNPs were biosynthesized from contaminated soil samples containing wastes from ceramics and photographic industries (10th of Ramadan City, Sharkia, Egypt) as described by [34]. Fungal isolate was screened to reduce the $\mathrm{AgNo}_{3}$ solution at $1 \mathrm{mM}$ to AgNPs according to El-Gazzar and Rabie [35]. The available salt of $\mathrm{AgNO}_{3}$ was donated from the NanoTech Egypt (Dreamland, Egypt). The physical properties and concentrations of the biosynthesized AgNPs were investigated.

The extracted DNA of the most potent suspected fungal isolate producing AgNPs was molecularly identified at the Biology Research Unit of the Assiut University using Patho Gene-spin DNA/RNA Extraction Kit (iNtRON Biotechnology, Seongnam, Korea) following the manufacturer's guidelines [36]. Isolates identified as Aspergillus spp. were further sequenced to target the same primers (SolGent, Daejeon, South Korea). The obtained sequence was analyzed using the BLAST tool and was placed in the GenBank (accession number MT319815). The nucleotide sequence was aligned with other sequences available at the GenBank to construct a phylogenetic tree using the MegAlign of DNASTAR program package (MegAlign 5.05, DNASTAR Inc., Madison, WI, USA). The recovered fungal isolate was characterized according to DeAlba-Montero, et al. [37] using different tools such as ultraviolet (UV)-visible spectrophotometer (T80 + UV Flash Spectrophotometer, PG Instruments Ltd., Wibtoft, UK); dynamic light scattering (DLS) system; transmission electron microscope (TEM) (JEOL.JEM.1010) at an accelerating voltage of $200 \mathrm{Kv}$; Fourier transform infrared spectroscopy (FTIR, Thermo Scientific Nicolet 6700 spectrometer) in the range of 400-4000 $\mathrm{cm}^{-1}$ and a resolution of $4 \mathrm{~cm}^{-1}$; and zeta potential analyzer (ZEN 1600, Malvern, UK).

\subsection{Antimicrobial Activity of Biosynthesized AgNPs}

The disk diffusion agar method was used to test the antimicrobial activity of biosynthesized AgNPs against S. enteritidis and S. typhimurium isolates [38]. A $10 \mu \mathrm{g}$ of the prepared nanoparticles were paced on standard disks with a diameter of $6 \mathrm{~mm}$ (Padtanteb, Qods, Iran). The S. enteritidis and S. typhimurium isolates were spread on the Mueller-Hinton broth (MHB) (Merck, Darmstadt, Germany). The disks were placed on the agar plate and a sterile blank disk was used as control; then, the inhibition zone was measured after a $24 \mathrm{~h}$ incubation at $37^{\circ} \mathrm{C}$.

Minimum inhibitory concentration (MIC) and minimum bactericidal concentration (MBC) values of biosynthesized AgNPs were determined using tube dilution method as previously described Krishnan, et al. [39]. Bacterial inoculums were adjusted to match a $0.5 \mathrm{McF}$ arland turbidity standard. A $100 \mu \mathrm{L}$ of AgNPs with different concentrations $(1,2,3$, $4,5,6,7,8,9$, and $10 \mu \mathrm{g} / \mathrm{mL})$ from each speed $(4000,8000$, and $14,000 \mathrm{rpm})$ and a $100 \mu \mathrm{L}$ from the tested organism were applied to $5 \mathrm{~mL}$ MHB and incubated at $37^{\circ} \mathrm{C}$ with shaking for $24 \mathrm{~h}$. Broth media with AgNPs inoculum was used as a positive control. The bacterial growth was monitored by measuring the mean OD at $600 \mathrm{~nm}$. 
The MBC was determined by coating the bacterial inoculum with different nanoparticle suspension concentrations into the MHA plate and then incubated at $37^{\circ} \mathrm{C}$ for $24 \mathrm{~h}$. The MBC value was defined as the lowest concentration, with no visible growths on the MHA plate.

\subsection{Virulence and Resistance Genes Expression \\ 2.7.1. Bacterial Counting}

The experiment used 2 MDR Salmonella isolates (S. enteritidis and S. typhimurium isolated during our study and were positive for most virulence and resistance genes). The bacterial inoculums were adjusted to $1.5 \times 10^{8}$ Colony Forming Unite $(\mathrm{CFU}) / \mathrm{mL}$. The surface plating method was used for the bacterial count on an agar plate [40]. Bacterial inoculums were inoculated with a final concentration of $5 \mu \mathrm{g} / \mathrm{mL}$ followed by constant stirring to obtain a uniform colloidal nanoparticle suspension. Nanoparticle-free medium was used as a positive control, whereas the bacteria-free medium was used as a negative control. Each inoculated suspension was incubated at $37{ }^{\circ} \mathrm{C}$ for $0,12,24,36$, and $48 \mathrm{~h}$. Bacterial growth inhibition was determined using the surface plating method by counting the number of CFUs on the plates. Bacteria and nanoparticle mixtures were prepared at different cultivation times. The amplification of the 16S rRNA gene was used to molecularly confirm Salmonella colonies. Bacterial cells were counted in triplicate and then the mean values and standard deviations were calculated.

\subsubsection{Quantitative Reverse Transcription PCR Analysis of Genes Expression}

At each sampling time, 1 volume of the harvested bacterial culture was added to 1 volume of RNAprotect Bacteria Reagent (Qiagen, Hilden, Germany) following the manufacturer's instructions. RNA isolation was implemented using QIAamp RNeasy Mini Kit (Qiagen, Hilden, Germany) according to the manufacturer's guidelines. SYBR Green I-based real-time PCR with the specific primers for $\operatorname{sop} B$, stn, and hilA virulence genes and blaTEM, tet $A$, and $n f s A$ resistance genes (which are all present in the used 2 Salmonella isolates) was performed and the 16S rRNA gene was used as a housekeeping gene [21]. The primers were used in a $25 \mu \mathrm{L}$ reaction containing $12.5 \mu \mathrm{L}$ of $2 \times$ QuantiTect SYBR Green PCR Master Mix (QIAGEN), $0.25 \mu \mathrm{L}$ of RevertAid Reverse Transcriptase $(200 \mathrm{U} / \mu \mathrm{L})$ (Thermo Fisher, Waltham, MA, USA), $0.5 \mu \mathrm{L}$ of each primer (20 pmoL concentration), $8.25 \mu \mathrm{L}$ of nuclease-free water, and $3 \mu \mathrm{L}$ of RNA template. The reaction was performed in a Stratagene MX3005P real-time PCR machine where the amplification curves and cycle threshold $(\mathrm{Ct})$ values were determined by Stratagene MX3005P software. The comparative $\mathrm{Ct}$ method was used to estimate the variations in RNA gene expression of the different samples by comparing $\mathrm{Ct}$ of each sample with that of the positive control. The $\Delta \Delta \mathrm{Ct}$ method was performed, according to Yuan, et al. [41].

\subsection{Statistical Analysis}

The R software (R Core Team, 2019; version 3.5.3) was used for the descriptive and statistical analysis. A heatmap was constructed based on the virulence and resistance genes and the antimicrobial susceptibility results using the R package "Complex heatmap" [42]. Nonmetric multidimensional scaling (nMDS) [43] was performed using the "metaMDS" function in "vegan" package to compare the dissimilarity of antimicrobial resistance profiles, using Bray-Curtis distance among isolates across all Salmonella spp. and within each species. The "corrplot" function in "corrplot" package was used to assess the correlation between the antimicrobial resistance and the presence of virulence and resistance genes. One-way analysis of variance was used to determine the significant difference between the bacterial counts and the fold change values of the gene's expression at each storage time. Multiple comparisons between the means were assessed by the Tukey's honestly significant difference test. $p<0.05$ was considered statistically significant. 


\section{Results}

\subsection{Salmonella spp. Isolation and Identification}

Salmonella spp. were identified in 83 of 431 examined samples (19.3\%) and were mostly identified in samples from laying hens (33.1\%) followed by humans $(22 \%)$ and table eggs (3.6\%) (Table 1). The most dominant Salmonella serotypes were S. enteritidis (5.8\%) and S. typhimurium (2.8\%), followed by S. kentucky (1.9\%), S. virchow (1.6\%), S. tamale, S. inganda, S. wingrove, S. bargny (1.2\%, each), S. Anatum ( $0.9 \%)$, S. tsavie, S. larochelle $(0.7 \%$, each), and S. apeyeme $(0.2 \%)$. On the other hand, only S. apeyeme was isolated from human samples (1 isolate), whereas S. anatum, S. tsavie, and S. larochelle were not identified (Table 1).

Table 1. Serotypes and pathotypes of Salmonella spp. isolated from laying hens, table eggs and humans.

\begin{tabular}{|c|c|c|c|c|c|}
\hline \multirow{2}{*}{ Serotypes } & \multirow{2}{*}{ Pathotypes } & \multicolumn{3}{|c|}{ No. (\%) of Isolates } & \multirow{2}{*}{$\begin{array}{c}\text { Total } \\
(n=431)\end{array}$} \\
\hline & & Laying Hens ( $n=166$ ) & Table Eggs $(n=165)$ & Humans $(n=100)$ & \\
\hline S.enteritidis & D1; O:1, 9, 12; H:g, m:- & $12(7.2)$ & $5(3.0)$ & $8(8.0)$ & $25(5.8)$ \\
\hline S.typhimurium & B; O:1, 4, 5, 12; H:i:1, 2 & $7(4.2)$ & $1(0.6)$ & $4(4.0)$ & $12(2.8)$ \\
\hline S.kentukey & C3; O:8, 20; H:i:z6 & $5(3.01)$ & $0(0.0)$ & $3(3.0)$ & $8(1.9)$ \\
\hline S.virchow & C1; O:6, 7, 14; H:r:1, 2 & $5(3.01)$ & $0(0.0)$ & $2(2.0)$ & $7(1.6)$ \\
\hline S.tamale & C3; O:8, 20; H:Z29:e, n, Z15 & $4(2.4)$ & $0(0.0)$ & $1(1.0)$ & $5(1.2)$ \\
\hline S.inganda & $\mathrm{C} 1 ; \mathrm{O}: 6,7 ; \mathrm{H}: \mathrm{Z10}: 1,5$ & $4(2.4)$ & $0(0.0)$ & $1(1.0)$ & $5(1.2)$ \\
\hline S.wingrove & C2; O:6, 8; H:c:1, 2 & $4(2.4)$ & $0(0.0)$ & $1(1.0)$ & $5(1.2)$ \\
\hline S.bargny & C3; O:8, 20; H:i:1, 5 & $4(2.4)$ & $0(0.0)$ & $1(1.0)$ & $5(1.2)$ \\
\hline S.anatum & E1; O:3, 10; H:e, h:1, 6 & $4(2.4)$ & $0(0.0)$ & $0(0.0)$ & $4(0.9)$ \\
\hline S.tsavie & B; O:4,5; H:i:e, n, z15 & $3(1.8)$ & $0(0.0)$ & $0(0.0)$ & $3(0.7)$ \\
\hline S.larochell & $\mathrm{C} 1 ; \mathrm{O}: 6,7 ; \mathrm{H}: \mathrm{e}, \mathrm{h}: 1,2$ & $3(1.8)$ & $0(0.0)$ & $0(0.0)$ & $3(0.7)$ \\
\hline S.apeyeme & C3; O:8, 20; H:Z38:- & $0(0.0)$ & $0(0.0)$ & $1(1.0)$ & $1(0.2)$ \\
\hline Total & & $55(33.1)$ & $6(3.6)$ & $22(22)$ & 83 (19.3) \\
\hline
\end{tabular}

\subsection{Antimicrobial Susceptibility Test}

The antimicrobial susceptibility profiles of the 25 S. enteritidis and 12 S. typhimurium isolates against 14 antimicrobial agents are presented in Table 2. All S. enteritidis and S. typhimurium isolates were resistant to AMP (100\%) and sensitive to MEM (100\%). In addition, $S$. enteritidis and $S$. typhimurium isolates exhibited high rates of resistance to tetracycline, NIT, and amoxicillin (Figure 1). The MDR was observed in 28 isolates (75.7\%) with a MAR index ranging from 0.21 to 0.57 .

Table 2. The antimicrobial resistance profile of S. enteritidis $(n=25)$ and S. typhimurium $(n=12)$ isolated from laying hens, table eggs, and humans.

\begin{tabular}{|c|c|c|c|c|c|c|c|}
\hline \multirow{2}{*}{$\begin{array}{l}\text { Antimicrobials } \\
\text { Class }\end{array}$} & \multirow{2}{*}{ Antimicrobials } & \multicolumn{3}{|c|}{ S. enteritidis Isolates (\%) } & \multicolumn{3}{|c|}{ S. typhimurium Isolates (\%) } \\
\hline & & $\mathbf{R}$ & $\mathbf{I}$ & $\mathbf{S}$ & $\mathbf{R}$ & $\mathbf{I}$ & $\mathbf{S}$ \\
\hline \multirow[t]{3}{*}{ Penicillin } & Ampicillin (AMP) & $25(100)$ & $0(0.0)$ & $0(0.0)$ & $12(100)$ & $0(0.0)$ & $0(0.0)$ \\
\hline & Ampicillin/Sulbactam (SAM) & $0(0.0)$ & $4(16.0)$ & $21(84.0)$ & $0(0.0)$ & $2(16.7)$ & $10(83.3)$ \\
\hline & Amoxicillin-Clavulanate (AMC) & $15(60.0)$ & $0(0.0)$ & $10(40.0)$ & $6(50.0)$ & $3(25.0)$ & $3(25.0)$ \\
\hline Cephalosporine & Cefataxime (CTX) & $9(36.0)$ & $0(0.0)$ & $16(64.0)$ & $3(25.0)$ & $0(0.0)$ & $9(75.0)$ \\
\hline Carbapenems & Imipenem (IPM) & $11(44.0)$ & $0(0.0)$ & $14(56.0)$ & $0(0.0)$ & $2(16.7)$ & $10(83.3)$ \\
\hline Aminoglycosides & Gentamicin (GEN) & $2(8.0)$ & $0(0.0)$ & $23(92.0)$ & $2(16.7)$ & $0(0.0)$ & $10(83.3)$ \\
\hline Tetracyclines & Tetracycline (TET) & $22(88.0)$ & $0(0.0)$ & $3(12.0)$ & $8(66.7)$ & $0(0.0)$ & $4(33.3)$ \\
\hline \multirow[t]{2}{*}{ Quinolones } & Ciprofloxacin (CIP) & $3(12.0)$ & $6(24.0)$ & $16(64.0)$ & $0(0.0)$ & $3(25.0)$ & $9(75.0)$ \\
\hline & Nalidixic acid (NAL) & $5(20.0)$ & $2(8.0)$ & $18(72.0)$ & $0(0.0)$ & $1(8.3)$ & $11(91.7)$ \\
\hline Sulphonamides & Trimethoprim-Sulfamethoxazole (SXT) & $0(0.0)$ & $5(20.0)$ & $20(80.0)$ & $1(8.3)$ & $2(16.7)$ & $9(75.0)$ \\
\hline Phenicols & Chloramphenicol (CHL) & $4(16.0)$ & $3(12.0)$ & $18(72.0)$ & $0(0.0)$ & $3(25.0)$ & $9(75.0)$ \\
\hline Macrolides & Azithromycin (AZM) & $5(20.0)$ & $0(0.0)$ & $20(80.0)$ & $4(33.3)$ & $0(0.0)$ & $8(66.7)$ \\
\hline Nitrofurans & Nitrofurantoin (NIT) & $20(80.0)$ & $0(0.0)$ & $5(20.0)$ & $8(66.7)$ & $0(0.0)$ & $4(33.3)$ \\
\hline Carbapenem & Meropenem (MEM) & $0(0.0)$ & $0(0.0)$ & $25(100)$ & $0(0.0)$ & $0(0.0)$ & $12(100)$ \\
\hline
\end{tabular}




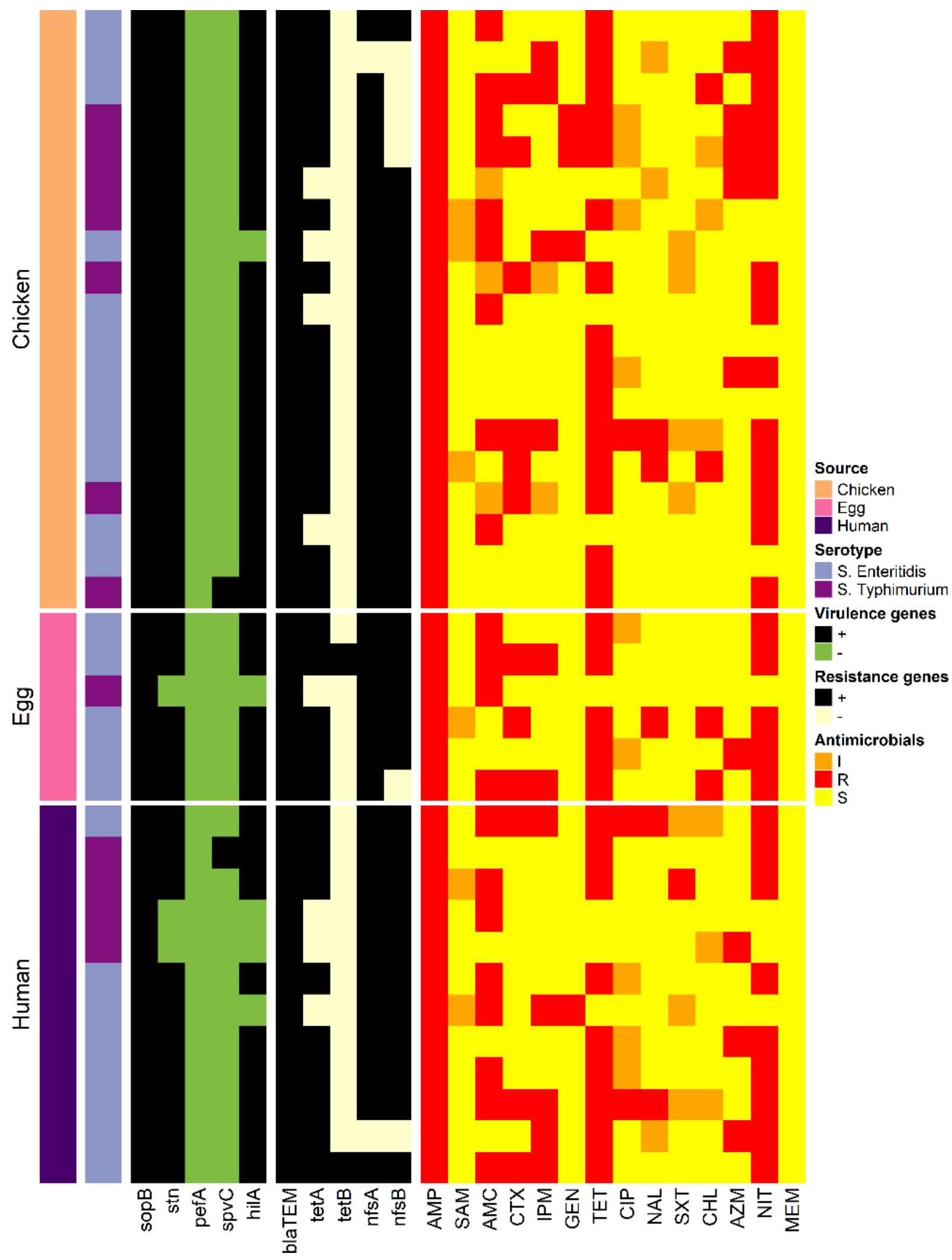

Figure 1. Heat map representation of the virulence and resistance genes and antimicrobial resistance profiles of $S$. enteritidis $(n=25)$ and $S$. typhimurium $(n=12)$ isolated from laying hens, table eggs, and humans. 
The nMDS plot (Figure 2) shows that the antimicrobial profiles of S. enteritidis and S. typhimurium isolated from chickens, eggs, and humans' samples were overlapped. The plot shows no evidence for clustering by isolate source.

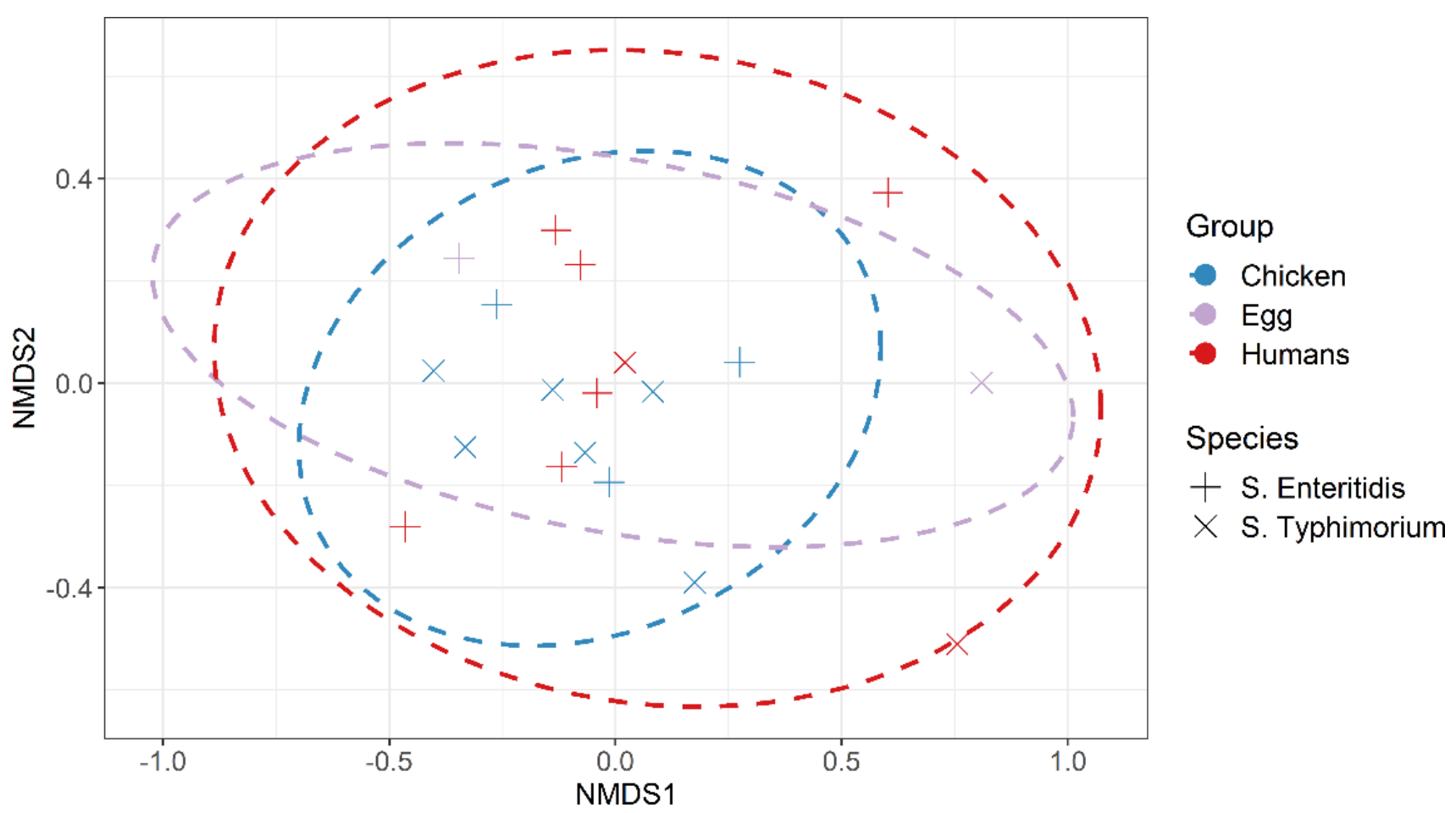

Figure 2. Non-metric multidimensional scaling ordination (NMDS) of antimicrobial-resistant of S. enteritidis and S. typhimurium isolated from laying hens, table eggs and humans.

\subsection{Virulence and Resistance Genes}

The presence of virulence and resistance-associated genes in S. enteritidis and S. typhimurium isolates is presented in Table 3. The $\triangle о p B$ gene was identified in all Salmonella spp. isolates, whereas the pefA gene was not detected in any isolate. The stn virulenceassociated gene was identified in all S. enteritidis and $75 \%$ of S. typhimurium isolates. The hilA gene was mostly identified in $94.6 \%$ of Salmonella isolates; however, the SpvC virulence gene was only detected in $5.4 \%$ of $S$. Typhimurium isolates. All Salmonella isolates (100\%) harbored only 1 virulence gene and 34 isolates $(91.9 \%)$ were positive for $>1$ virulence gene (Figure 1).

Five resistance genes (blaTEM, tet $A, \operatorname{tet} B, n f_{S} A$ and $\left.n f_{s} B\right)$ were also identified in S. enteritidis and S. typhimurium isolates (Table 3). The blaTEM gene was identified in all isolates and most isolates harbored $n f_{s} A(94.6 \%)$ and $n f_{s} B$ and tet $A(83.8 \%$, each) resistance genes. However, the tet $B$ resistance gene was only recognized in two $S$. enteritidis isolates. Notably, five resistance profiles were exhibited in the study and most isolates $(56.8 \%)$ were related to a profile carrying four resistance genes (blaTEM, tet $A, n f s A$ and $n f s B$ ) (Figure 1).

Significant correlations between resistance genes and antimicrobial agents are presented in Figure 3. There were significant positive correlations between resistance genes and their corresponding antimicrobial agents in most cases. The analysis also showed a significant negative correlation between resistance genes and antimicrobial agents other than the corresponding ones. 
Table 3. Virulence and resistance genes and antimicrobial resistance patterns of S. enteritidis $(n=25)$ and S. typhimurium $(n=12)$ isolated from laying hens, table eggs and humans.

\begin{tabular}{|c|c|c|c|c|c|c|c|c|c|c|c|c|c|c|}
\hline \multirow{2}{*}{ Source } & \multirow{2}{*}{$\begin{array}{l}\text { No. of } \\
\text { Isolates }\end{array}$} & \multicolumn{5}{|c|}{ Virulence Genes } & \multicolumn{5}{|c|}{ Resistance Genes } & \multirow{2}{*}{$\begin{array}{l}\text { No. of } \\
\mathbf{A b}\end{array}$} & \multirow{2}{*}{ Resistance Patterns } & \multirow{2}{*}{ MARIndex } \\
\hline & & sopB & stn & pefA & spvC & hilA & blaTEM & tetA & tetB & $n f s A$ & $n f s B$ & & & \\
\hline \multicolumn{15}{|c|}{ (I) S. enteritidis } \\
\hline Human & 2 & + & + & - & - & + & + & + & - & + & + & 8 & AMP, AMC, CTX, IPM, TET, CIP, NA, NIT & 0.57 \\
\hline Chicken & 1 & + & + & - & - & + & + & + & - & + & - & 7 & AMP, AMC, CTX, IPM, TET, NA, NIT & 0.50 \\
\hline Egg & 1 & + & + & - & - & + & + & + & - & + & - & 7 & AMP, AMC, CTX, IPM, TET, NA, NIT & 0.50 \\
\hline Egg & 1 & + & + & - & - & + & + & + & + & + & + & 6 & AMP, AMC, CTX, IPM, TET, NIT & 0.43 \\
\hline Human & 1 & + & + & - & - & + & + & + & + & + & + & 6 & AMP, AMC, CTX, IPM, TET, NIT & 0.43 \\
\hline Egg & 1 & + & + & - & - & + & + & + & - & + & + & 6 & AMP, CTX, IPM, TET, NAL, NIT & 0.43 \\
\hline Chicken & 1 & + & + & - & - & + & + & + & - & - & - & 5 & AMP, IPM, TET, AZM, NIT & 0.36 \\
\hline Human & 1 & + & + & - & - & + & + & + & - & - & - & 5 & AMP, IPM, TET, AZM, NIT & 0.36 \\
\hline Chicken & 1 & + & + & - & - & + & + & + & - & + & + & 4 & AMP, AMC, TET, NIT & 0.29 \\
\hline Egg & 1 & + & + & - & - & + & + & + & - & + & + & 4 & AMP, AMC, TET, NIT & 0.29 \\
\hline Human & 2 & + & + & - & - & + & + & + & - & + & + & 4 & AMP, AMC, TET, NIT & 0.29 \\
\hline Egg & 1 & + & + & - & - & + & + & + & - & + & + & 4 & AMP, TET, AZM, NIT & 0.29 \\
\hline Chicken & 1 & + & + & - & - & + & + & + & - & + & + & 4 & AMP, TET, AZM, NIT & 0.29 \\
\hline Human & 1 & + & + & - & - & + & + & + & - & + & + & 4 & AMP, TET, AZM, NIT & 0.29 \\
\hline Chicken & 1 & + & + & - & - & - & + & - & - & + & + & 4 & AMP, AMC, IPM, GEN & 0.29 \\
\hline Human & 1 & + & + & - & - & - & + & - & - & + & + & 4 & AMP, AMC, IPM, GEN & 0.29 \\
\hline \multicolumn{15}{|c|}{ (II) S. typhimurium } \\
\hline Chicken & 1 & + & + & - & - & + & + & + & - & + & - & 7 & AMP, AMC, CTX, GEN, TET, AZM, NIT & 0.50 \\
\hline Chicken & 1 & + & + & - & - & + & + & + & - & + & - & 6 & AMP, AMC, GEN, TET, AZM, NIT & 0.43 \\
\hline Human & 1 & + & + & - & - & + & + & + & - & + & + & 5 & AMP, AMC, TET, SXT, NIT & 0.36 \\
\hline Chicken & 2 & + & + & - & - & + & + & + & - & + & + & 4 & AMP, CTX, TET, NIT & 0.29 \\
\hline Human & 1 & + & + & - & + & + & + & + & - & + & + & 3 & AMP, TET, NIT & 0.21 \\
\hline Chicken & 1 & + & + & - & + & + & + & + & - & + & + & 3 & AMP, TET, NIT & 0.21 \\
\hline Chicken & 1 & + & + & - & - & + & + & - & - & + & + & 3 & AMP, AZM, NIT & 0.21 \\
\hline Chicken & 1 & + & + & - & - & + & + & + & - & + & + & 3 & AMP, AMC, TET & 0.21 \\
\hline Human & 1 & + & - & - & - & - & + & - & - & + & + & 2 & AMP, AMC & 0.14 \\
\hline Egg & 1 & + & - & - & - & - & + & - & - & + & + & 2 & AMP, AMC & 0.14 \\
\hline Human & 1 & + & - & - & - & - & + & - & - & + & + & 2 & AMP, AZM & 0.14 \\
\hline
\end{tabular}


S. Enteritidis

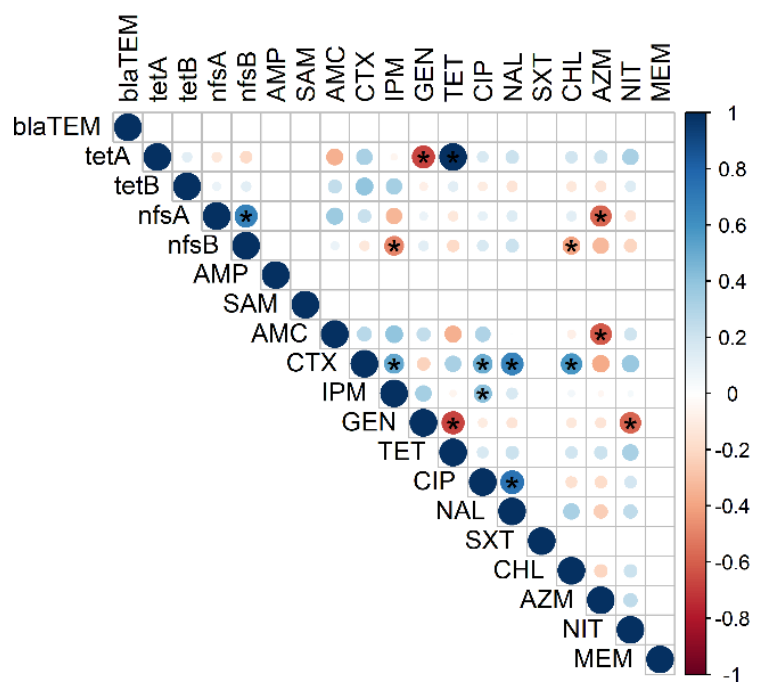

S. Typhimurium

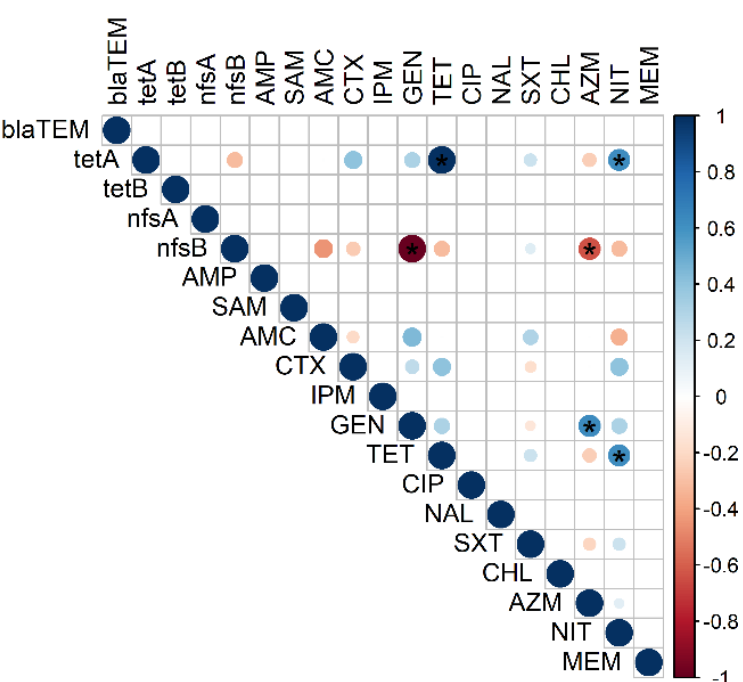

Figure 3. Correlation matrix showing the correlation between resistance phenotypes and genotypes among the examined S. enteritidis and S. typhimurium isolates recovered from laying hens, table eggs, and humans. The blue colour indicates a positive correlation and red shows a negative correlation. The asterisk $\left(^{*}\right)$ indicates significant at $p<0.001$.

\subsection{Characterization of Biosynthesized AgNPs}

AgNPs were synthesized from Aspergillus niveus (A. niveus; MT319815), molecularly confirmed in the study targeting the $28 \mathrm{~S}$ rRNA region (Figure $4 \mathrm{~A}$ ). AgNPs were oval, cubic, rod shaped, and well distributed without agglomeration at $6.49 \mathrm{~nm}$ using TEM microscopy (Figure 4B). The prepared AgNPs were characterized by the absorption peak of AgNPs at $420 \mathrm{~nm}$ using the UV-visible spectrum and an average particle size at $27 \mathrm{~nm}$ using DLS (Figure 4C). FTIR spectra of AgNPs confirmed the presence of various functional groups at $3451.81,2081.40,1634.19,1384.39,1117.76$, and $614.02 \mathrm{~cm}^{-1}$. The peaks at 3451.81 , 2081.40, 1634.19, and $614.02 \mathrm{~cm}^{-1}$ correspond to carbonyl residues, alcohol, nitrile, acid chloride, and alkene band $\mathrm{C}-\mathrm{C}$ stretch in ring of $\mathrm{CH} 3$, stretch of alkyl halides and peptide bonds of proteins responsible for the synthesis of the AgNPs (Figure 4D). The bands at $3451.81,1634.19$, and $1384.39 \mathrm{~cm}^{-1}$ correspond to the binding vibrations of amide I and amide II of protein and hydroxyl O-H stretch of phenols with amine $\mathrm{N}-\mathrm{H}$ stretchings. In addition, the band at $1117.76 \mathrm{~cm}^{-1}$ refers to one mononuclear aromatic. Dynamic light scattering analysis showed that the average particle size of the prepared AgNPs was at $27 \mathrm{~nm}$ (Figure 4E). The stability degree (Zeta Potential) of AgNPs showed a negative charge at $-30.4 \mathrm{mv}$ (Figure $4 \mathrm{~F}$ ).

\subsection{Antimicrobial Activity of Biosynthesized AgNPs}

The disk diffusion method was used to evaluate the antimicrobial activity of S. enteritidis and S. typhimurium isolates treated with AgNPs. The diameter of inhibition zones of $\operatorname{AgNP}(10 \mu \mathrm{g})$-treated S. enteritidis and S. typhimurium isolates were $24 \mathrm{~mm}$ and $20 \mathrm{~mm}$, respectively. The MIC for Salmonella treated with different concentrations (10, 9, 8, 7, 6, $5,4,3,2$, and $1 \mu \mathrm{g} / \mathrm{mL}$ ) in this study was $5 \mu \mathrm{g} / \mathrm{mL}$ upon using the dilution method to S. enteritidis and S. typhimurium isolates, whereas MBC value was $6 \mu \mathrm{g} / \mathrm{mL}$ to $S$. enteritidis isolates and $8 \mu \mathrm{g} / \mathrm{mL}$ to $S$. typhimurium isolates.

The selected MBC value for each strain was evaluated by assessing the bacterial growth $(\mathrm{CFU} / \mathrm{mL}$ ) at time intervals $12,24,36$, and $48 \mathrm{~h}$ (Figure 5). The growth of $S$. enteritidis and S. typhimurium significantly $(p<0.05)$ declined at $12 \mathrm{~h}$ and reached complete inhibition at $48 \mathrm{~h}$. In parallel, the control plates showed a significant increase in growth. 

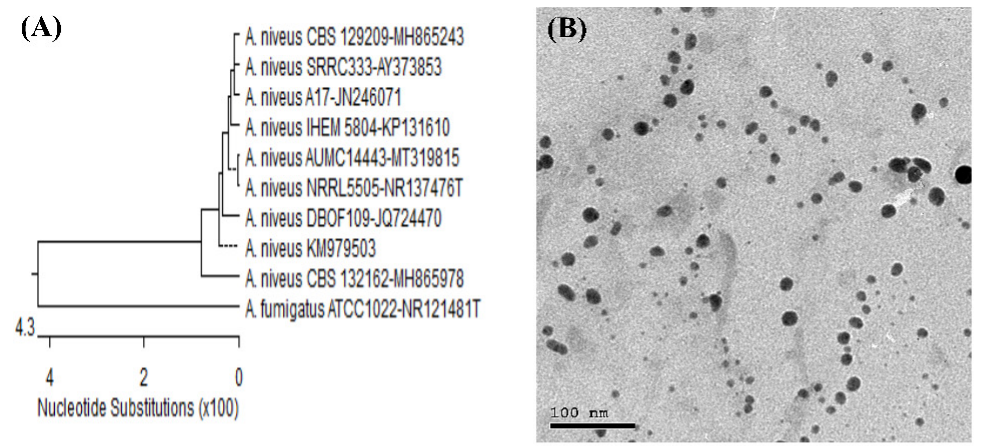

(E)

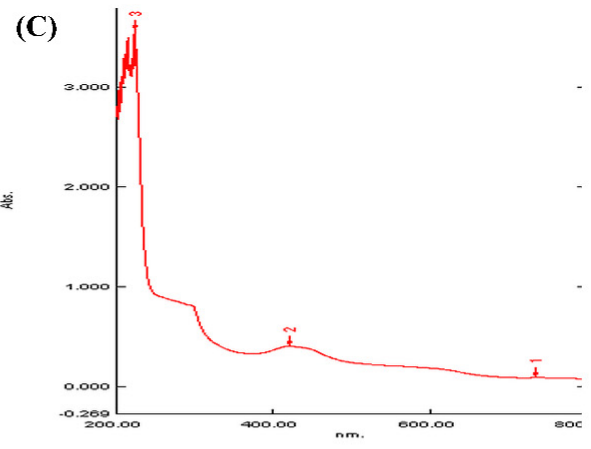

Size Distribution by Number
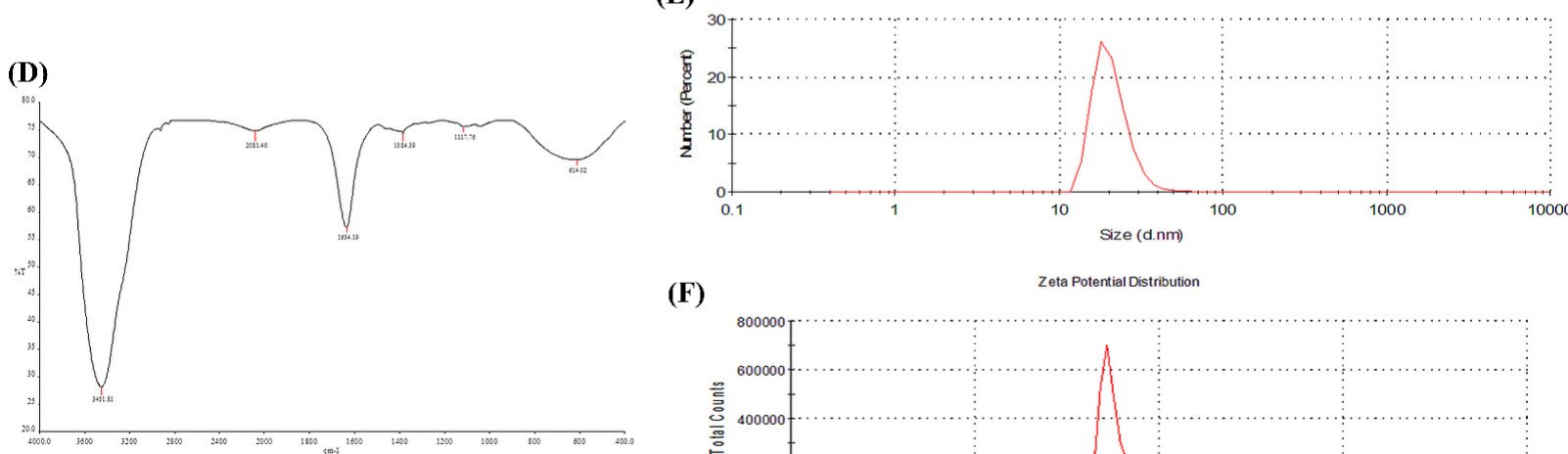

(F)

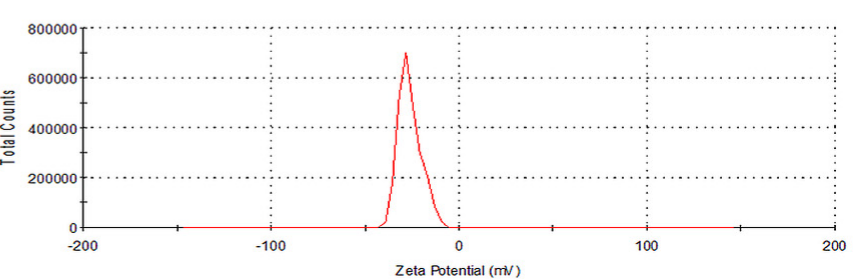

Figure 4. Characterization of AgNPs. (A) Phylogenetic analysis of the Aspergillus niveus (MT319815) used in the biosynthesis of AgNPs; (B) TEM micrographs and size distribution for silver (scale bar: $100 \mathrm{~nm}$ ); (C) UV-Visible spectrum of AgNPs; (D) Fourier transform infrared spectrum showing the functional groups on the surface of AgNPs; (E) Dynamic light scattering analysis showing the highest peak at $27 \mathrm{~nm}$ and (F) Zeta-potential of AgNPs.

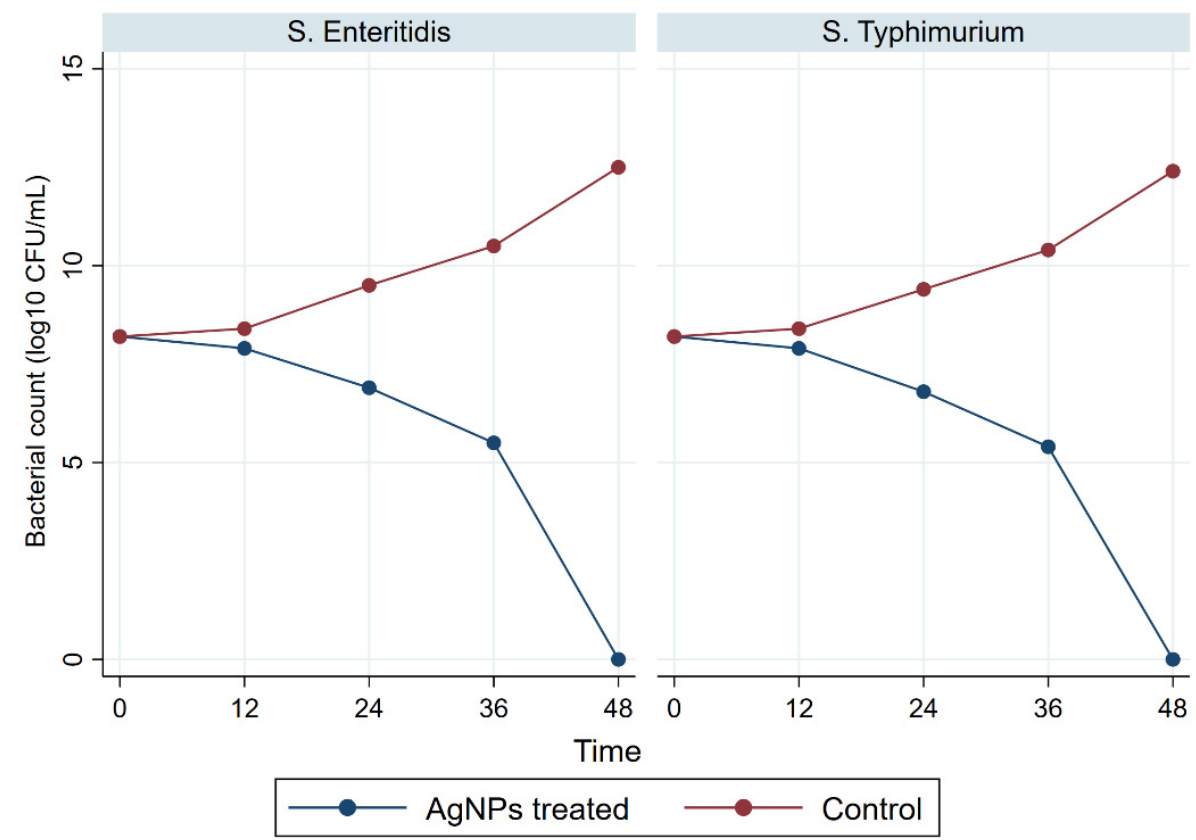

Figure 5. Bacterial growth of multidrug-resistant S. enteritidis and S. typhimurium treated with AgNPs. Bacterial counts were recorded at $0,12,24,36$, and $48 \mathrm{~h}$ post-treatment. 


\subsection{Antivirulent and Antiresistant Activity of Biosynthesized AgNPs}

The expression patterns of virulence and resistance genes of S. enteritidis and S. typhimurium isolates treated with AgNPs at time intervals 6, 12, 24, and $36 \mathrm{~h}$ are presented in Table 4 . The expression levels of virulence and resistance genes significantly decreased by time. Despite the loss of expression of the virulence genes at $36 \mathrm{~h}$, the resistance genes showed instant expression.

Table 4. Virulence and resistance genes expression of multidrug-resistant S. enteritidis and S. typhimurium treated with AgNPs.

\begin{tabular}{|c|c|c|c|c|c|c|}
\hline \multirow{2}{*}{$\begin{array}{l}\text { Storage Time } \\
\text { (Hours) }\end{array}$} & \multicolumn{3}{|c|}{ Virulence Genes Expression } & \multicolumn{3}{|c|}{ Resistance Genes Expression } \\
\hline & SopB & stn & hilA & blaTEM & tet $A$ & $n f s A$ \\
\hline \multicolumn{7}{|c|}{ (I) S. enteritidis } \\
\hline 0 & $1.0 \pm 0.0$ & $1.0 \pm 0.0$ & $1.0 \pm 0.0$ & $1.0 \pm 0.0$ & $1.0 \pm 0.0$ & $1.0 \pm 0.0$ \\
\hline 6 & $0.71 \pm 0.015$ & $0.73 \pm 0.025$ & $0.69 \pm 0.015$ & $0.85 \pm 0.02$ & $0.78 \pm 0.01$ & $0.83 \pm 0.006$ \\
\hline 12 & $0.45 \pm 0.015$ & $0.44 \pm 0.015$ & $0.41 \pm 0.015$ & $0.69 \pm 0.01$ & $0.61 \pm 0.01$ & $0.66 \pm 0.015$ \\
\hline 24 & $0.11 \pm 0.001$ & $0.26 \pm 0.02$ & $0.15 \pm 0.025$ & $0.46 \pm 0.01$ & $0.42 \pm 0.006$ & $0.47 \pm 0.006$ \\
\hline 36 & $0.0 \pm 0.0$ & $0.0 \pm 0.0$ & $\begin{array}{c}0.0 \pm 0.0 \\
\text { (II) S. typhimurium }\end{array}$ & $0.16 \pm 0.006$ & $0.11 \pm 0.01$ & $0.14 \pm 0.006$ \\
\hline 0 & $1.0 \pm 0.0$ & $1.0 \pm 0.0$ & $1.0 \pm 0.0$ & $1.0 \pm 0.0$ & $1.0 \pm 0.0$ & $1.0 \pm 0.0$ \\
\hline 6 & $0.77 \pm 0.02$ & $0.79 \pm 0.01$ & $0.76 \pm 0.01$ & $0.92 \pm 0.015$ & $0.87 \pm 0.02$ & $0.94 \pm 0.015$ \\
\hline 12 & $0.49 \pm 0.02$ & $0.47 \pm 0.025$ & $0.42 \pm 0.01$ & $0.82 \pm 0.02$ & $0.56 \pm 0.01$ & $0.79 \pm 0.01$ \\
\hline 24 & $0.23 \pm 0.025$ & $0.26 \pm 0.025$ & $0.15 \pm 0.025$ & $0.59 \pm 0.01$ & $0.34 \pm 0.015$ & $0.57 \pm 0.01$ \\
\hline 36 & $0.0 \pm 0.0$ & $0.0 \pm 0.0$ & $0.0 \pm 0.0$ & $0.38 \pm 0.015$ & $0.18 \pm 0.015$ & $0.36 \pm 0.015$ \\
\hline
\end{tabular}

\section{Discussion}

Chicken and eggs are considered one of the main reservoirs for zoonotic pathogens [44]. In this study, 12 different Salmonella serovars were identified in the examined samples with Salmonella spp. prevalence of $19.3 \%$, and most of them were identified in laying hen samples $(33.1 \%)$. The observed prevalence in laying hens was comparable to the $32.0 \%$ reported recently in Egypt [45] and the 33.3\% in Colombia [46], but higher than the $1.02 \%$ and $10.4 \%$ reported in Spain [47] and Egypt [48], respectively. However, the prevalence of Salmonella spp. infection in laying hens was lower than the $59.3 \%$ that was reported previously in Korea [20]. Furthermore, the prevalence of Salmonella spp. infection in human samples (22\%) was higher than the $4 \%$ that was reported previously in the same governorate [49]. In this study, the isolation rate of Salmonella spp. from egg content was low (3.6\%) and lower than the 5.2\% reported by Im, Jeong, Kwon, Jeong, Kang, and Lee [20] and the absence of Salmonella in egg content reported by Zubair, et al. [50]. The low incidence of Salmonella in egg content was caused by the egg's complex system of membrane barriers and the albumen antibacterial effect [51]. Furthermore, Salmonella in egg contents may be attributed to contamination of eggshell by Salmonella infected poultry feces, which may penetrate the interior of eggs and grow during storage [52].

S. enteritidis and S. typhimurium were the most commonly isolated serotypes in this study, which was consistent with previous reports from Egypt [45] and Brazil [53]. The S. enteritidis and S. typhimurium isolates used in this study showed a high rate of antimicrobial resistance (100\%) to at least one antimicrobial agent. Antimicrobial agents (AMP, TET, and NIT) were not effective against Salmonella isolates in this study. Our findings were comparable to those reported previously in South India [54] and Ghana [55]. The high rate of resistance reported in this study could be attributed to a number of factors, including the overuse of antimicrobial agents (over-the-counter antibiotics without a prescription) and the inappropriate use of antimicrobial agents as a growth promoter in animals, which could lead to the emergence of resistant bacteria in both animals and humans through direct contact or through the food chain [56]. All Salmonella isolates in this study were sensitive to SAM and MEM, which was consistent with previous Egyptian reports [57,58], and was accredited to the limited use of these antimicrobial agents in commercial chicken farms. 
Previously, MDR from various sources has been identified in Salmonella [57,59], making these antimicrobial agents ineffective in humans and poultry [60]. In the current study, $75.7 \%$ of Salmonella isolates displayed MDR, which is higher than the prevalence of MDR Salmonella isolated from chicken in the USA [61] and China [62,63]. Despite this, the prevalence of MDR Salmonella in this study was lower than the $100 \%$ previously reported in chicken in Egypt [57] and 92.9\% in North India [59]. The resistant isolates were not evenly distributed in laying hens, eggs, and humans. However, these isolates were overlapped, reflecting the high public health impact of MDR isolates and the need for new antimicrobial agents to treat human salmonellosis [64].

The presence of both virulence and antimicrobial resistance genes affects the bacteria' pathogenicity [8]. The emergence of MDR strains of Salmonella is primarily due to genetic factors that enhance their survival by retaining drug resistance genes [65]. Of the confirmed S. enteritidis and S. typhimurium isolates, $81.1 \%$ harbored three virulence genes (sopB, stn, and hilA), which was similar to the previous study in Malaysia [66]. None of the isolates harbored pefA gene in our study, which was similar to a previous study in Egypt [45]. In contrast to Thung, Radu, Mahyudin, Rukayadi, Zakaria, Mazlan, Tan, Lee, Yeoh, and Chin [66], who reported the absence of spvC gene Salmonella isolates, the spvC was identified in $5.4 \%$ of S. enteritidis and S. typhimurium isolates.

In the present study, Salmonella harbors a range of antibiotic resistance genes located on mobile genetic elements that distribute resistance characteristics to other serovars and other different bacteria [59]. All isolates had blaTEM resistance genes and most of them had tet $A, n f_{s} A$, and $n f s B$ resistance genes, which was similar to Salmonella isolates from chickens in Egypt [57] and North India [59]. The Tet $B$ was not identified in previous studies, but tet $A$ was the most common, highlighting its resistance role to tetracyclines [59,67].

There is currently a need for more research to find novel materials that inhibit antimicrobial-resistant variants [68]. Therefore, the development of natural antimicrobial agents such as AgNPs may be an alternative way to overcome MDR bacteria. In our study, AgNPs were biosynthesized from molecularly confirmed A. nivus. in line with the previous study by Elgazzar and Ismail [69], the peak of AgNPs using UV-visible spectra was witnessed at $420 \mathrm{~nm}$. The small particle size of AgNPs $(27 \mathrm{~nm})$ with a single peak indicates the suitable quality of the biosynthesized nanoparticles and ideal inhibitory effects on bacterial growth [70]. The small particle size allows AgNPs to bind to the cell wall and easily penetrate the bacteria cell, enhancing their antimicrobial activity against the bacteria owing to their larger surface area and greater interaction [71]. The TEM microscopy indicated that biosynthesized AgNPs were well dispersed in the solution without agglomeration, explaining that fungal filtrates contain various biomolecules used to cap and stabilize the agglomeration of AgNPs [35]. FTIR measurements of biosynthesized AgNPs have verified different functional groups of biomolecules and capped proteins, excreted by the fungus itself, encapsulated nanoparticles, and increased stability; associated proteins may help to mineralize precursor salts [69]. The higher negative charge of the AgNPs as measured by the zeta potential confirms the synthesized particles' repulsion, resulting in stability and monodispersity of the synthesized AgNPs solution [72].

In this study, a clear zone was found to exist around the AgNP disk, suggesting that the biosynthesized AgNPs possessed a potent antibacterial effect against the growth of MDR bacteria, causing a reduction in bacterial number [73,74]. To evaluate the effect of AgNPs against Salmonella, MIC and MBC values were examined in our study, showing the extent of variation with Loo, et al. [74], who reported that the MIC value of S. enteritidis and S. typhimurium was $3.9 \mathrm{mg} / \mathrm{mL}$ (each) and the $\mathrm{MBC}$ values for S. enteritidis and S. typhimurium were $3.9 \mathrm{mg} / \mathrm{mL}$ and $7.8 \mathrm{mg} / \mathrm{mL}$, respectively.

The bacterial growth inhibition of AgNPs occurs because AgNPs interfere with sulfur found in biomolecules on the bacterial membrane, attacking the bacterial genome and resulting in bacterial death [75]. In this study, a significant decrease was found in the number of Salmonella isolates after different storage time and the growth was completely absent after $48 \mathrm{~h}$ of incubation; however, Tanhaeian and Ahmadi [76] reported a decline 
in the bacterial growth treated with $25 \mu \mathrm{g} / \mathrm{mL}$ and $50 \mu \mathrm{g} / \mathrm{mL}$ of AgNP after $10 \mathrm{~h}$ and the growth level dropped to almost zero.

Besides exploring the effect of the biosynthesized AgNPs on the growth inhibition of Salmonella, we investigated their impact on the expression of genes that are essential to the virulence and resistance of the pathogen. The results emphasized that biosynthesized AgNPs at a concentration of $5 \mu \mathrm{g}$ significantly reduce gene expression, as previously reported [76]. The adverse effect of the biosynthesized AgNPs on virulence and resistance genes expression contributes to effective preventative and potent antimicrobial drugs against bacterial infection [76]. AgNPs are broad-spectrum antimicrobial agents that have the same effect on all Gram-negative bacteria strains. However, the concentration of the used AgNPs and bacteria class, nanoparticle size, synthesis method, and physical characteristics of nanoparticles are key factors that can affect the results across studies.

\section{Conclusions}

In the present study, S. enteritidis and S. typhimurium were the most common Salmonella serovars isolated from laying hens, table eggs, and humans in Egypt. Moreover, most of the recovered Salmonella isolates exhibited MDR, which poses a possible risk to consumers in Egypt. The findings of this study support that AgNPs have the potential to be effective antimicrobial agents against MDR S. enteritidis and S. typhimurium and could be recommended for use in laying hen farms. However, further studies are required to develop and design a safe AgNPs antimicrobial for laying hen farms.

Author Contributions: Conceptualization, R.M.M.A.E.; I.E.; N.E.-G.; H.M.N.T.; E.N.A.; A.A.M.; S.S.A., and A.B.M.B.T.; methodology, R.M.M.A.E.; N.E.-G.; H.M.N.T.; E.N.A.; A.A.M.; S.S.A., and A.B.M.B.T.; software, R.M.M.A.E.; I.E., and N.E.-G.; validation, R.M.M.A.E.; N.E.-G.; H.M.N.T.; E.N.A.; A.A.M.; S.S.A., and A.B.M.B.T.; formal analysis, I.E.; investigation, R.M.M.A.E. and A.B.M.B.T.; resources, N.E.-G.; H.M.N.T.; E.N.A.; A.A.M., and S.S.A.; data curation, R.M.M.A.E.; N.E.-G.; A.A.M., and A.B.M.B.T.; writing-original draft preparation, R.M.M.A.E.; I.E.; N.E.-G., and A.B.M.B.T.; writing-review and editing, R.M.M.A.E.; I.E.; N.E.-G.; H.M.N.T.; E.N.A.; A.A.M.; S.S.A., and A.B.M.B.T.; visualization, R.M.M.A.E.; I.E.; N.E.-G., and A.B.M.B.T.; supervision, R.M.M.A.E.; project administration, R.M.M.A.E. and A.B.M.B.T. All authors have read and agreed to the published version of the manuscript.

Funding: No specific funding was received.

Institutional Review Board Statement: This study was approved by the Institutional Animal Care and Use Committee (IACUC) of Zagazig University (Ref. No.: ZU-IACUC/2/F/7/2020).

Informed Consent Statement: Informed consent was obtained from all subjects involved in the study.

Data Availability Statement: The data presented in this study are available on request from the corresponding author.

Acknowledgments: The authors thank the participants (laying hens farms and patients) who agreed to use their samples in this study. Authors would also thank the Egyptian Knowledge Bank (EKB) for editing and grammar correction of this manuscript.

Conflicts of Interest: The authors declare no conflict of interest.

\section{References}

1. Majowicz, S.E.; Musto, J.; Scallan, E.; Angulo, F.J; Kirk, M.; O’Brien, S.J.; Jones, T.F.; Fazil, A.; Hoekstra, R.M. The global burden of nontyphoidal Salmonella gastroenteritis. Clin. Infect. Dis. 2010, 50, 882-889. [CrossRef]

2. Ceyssens, P.J.; Mattheus, W.; Vanhoof, R.; Bertrand, S. Trends in serotype distribution and antimicrobial susceptibility in Salmonella enterica isolates from humans in Belgium, 2009 to 2013. Antimicrob. Agents Chemother. 2015, 59, 544-552. [CrossRef] [PubMed]

3. Jackson, B.R.; Griffin, P.M.; Cole, D.; Walsh, K.A.; Chai, S.J. Outbreak-associated Salmonella enterica serotypes and food commodities, United States, 1998-2008. Emerg. Infect. Dis. 2013, 19, 1239-1244. [CrossRef]

4. De Reu, K.; Grijspeerdt, K.; Messens, W.; Heyndrickx, M.; Uyttendaele, M.; Debevere, J.; Herman, L. Eggshell factors influencing eggshell penetration and whole egg contamination by different bacteria, including Salmonella enteritidis. Int. J. Food Microbiol. 2006, 112, 253-260. [CrossRef] 
5. Li, R.; Lai, J.; Wang, Y.; Liu, S.; Li, Y.; Liu, K.; Shen, J.; Wu, C. Prevalence and characterization of Salmonella species isolated from pigs, ducks and chickens in Sichuan Province, China. Int. J. Food Microbiol. 2013, 163, 14-18. [CrossRef]

6. Heider, L.C.; Funk, J.A.; Hoet, A.E.; Meiring, R.W.; Gebreyes, W.A.; Wittum, T.E. Identification of Escherichia coli and Salmonella enterica organisms with reduced susceptibility to ceftriaxone from fecal samples of cows in dairy herds. Am. J. Vet. Res. 2009, 70, 389-393. [CrossRef]

7. Elemfareji, O.I.; Thong, K.L. Comparative Virulotyping of Salmonella typhi and Salmonella enteritidis. Indian J. Microbiol. 2013, 53, 410-417. [CrossRef]

8. Huehn, S.; La Ragione, R.M.; Anjum, M.; Saunders, M.; Woodward, M.J.; Bunge, C.; Helmuth, R.; Hauser, E.; Guerra, B.; Beutlich, J. Virulotyping and antimicrobial resistance typing of Salmonella enterica serovars relevant to human health in Europe. Foodborne Pathog. Dis. 2010, 7, 523-535. [CrossRef] [PubMed]

9. Murugkar, H.; Rahman, H.; Dutta, P. Distribution of virulence genes in Salmonella serovars isolated from man \& animals. Indian J. Med. Res. 2003, 117, 66-70.

10. Fluit, A.C. Towards more virulent and antibiotic-resistant Salmonella? FEMS Immunol. Med. Microbiol. 2005, 43, 1-11. [CrossRef]

11. Zishiri, O.T.; Mkhize, N.; Mukaratirwa, S. Prevalence of virulence and antimicrobial resistance genes in Salmonella spp. isolated from commercial chickens and human clinical isolates from South Africa and Brazil. Onderstepoort J. Vet. Res. 2016, 83, 1-11. [CrossRef]

12. Shaalan, M.; Saleh, M.; El-Mahdy, M.; El-Matbouli, M. Recent progress in applications of nanoparticles in fish medicine: A review. Nanomed. Nanotechnol. Biol. Med. 2016, 12, 701-710. [CrossRef]

13. Agnihotri, S.; Mukherji, S.; Mukherji, S. Size-controlled silver nanoparticles synthesized over the range 5-100 $\mathrm{nm}$ using the same protocol and their antibacterial efficacy. RSC Adv. 2014, 4, 3974-3983. [CrossRef]

14. Franci, G.; Falanga, A.; Galdiero, S.; Palomba, L.; Rai, M.; Morelli, G.; Galdiero, M. Silver nanoparticles as potential antibacterial agents. Molecules 2015, 20, 8856-8874. [CrossRef] [PubMed]

15. Gurunathan, S. Biologically synthesized silver nanoparticles enhance antibiotic activity against Gram-negative bacteria. J. Ind. Eng. Chem. 2015, 29, 217-226. [CrossRef]

16. Iravani, S.; Korbekandi, H.; Mirmohammadi, S.V.; Zolfaghari, B. Synthesis of silver nanoparticles: Chemical, physical and biological methods. Res. Pharm. Sci. 2014, 9, 385-406.

17. Khodashenas, B.; Ghorbani, H.R. Synthesis of silver nanoparticles with different shapes. Arab. J. Chem. 2019, 12, 1823-1838. [CrossRef]

18. El-Gohary, F.A.; Abdel-Hafez, L.J.M.; Zakaria, A.I.; Shata, R.R.; Tahoun, A.; El-Mleeh, A.; Elfadl, E.A.A.; Elmahallawy, E.K. Enhanced Antibacterial Activity of Silver Nanoparticles Combined with Hydrogen Peroxide Against Multidrug-Resistant Pathogens Isolated from Dairy Farms and Beef Slaughterhouses in Egypt. Infect. Drug Resist. 2020, 13, 3485-3499. [CrossRef]

19. Lange, A.; Grzenia, A.; Wierzbicki, M.; Strojny-Cieslak, B.; Kalińska, A.; Gołębiewski, M.; Radzikowski, D.; Sawosz, E.; Jaworski, S. Silver and copper nanoparticles inhibit biofilm formation by mastitis pathogens. Animals 2021, 11, 1884. [CrossRef] [PubMed]

20. Im, M.C.; Jeong, S.J.; Kwon, Y.-K.; Jeong, O.-M.; Kang, M.-S.; Lee, Y.J. Prevalence and characteristics of Salmonella spp. isolated from commercial layer farms in Korea. Poult. Sci. 2015, 94, 1691-1698. [CrossRef]

21. Yang, X.; Brisbin, J.; Yu, H.; Wang, Q.; Yin, F.; Zhang, Y.; Sabour, P.; Sharif, S.; Gong, J. Selected lactic acid-producing bacterial isolates with the capacity to reduce Salmonella translocation and virulence gene expression in chickens. PLoS ONE 2014, 9, e93022. [CrossRef] [PubMed]

22. McFaddin, J. Biochemical Tests for Identification of Medical Bacteria; Lippicott Williams Wilkins: Philadelphia, PA, USA, 2000.

23. Kauffman, G. Kauffmann white scheme. J. Acta. Path. Microbiol. Sci. 1974, 61, 385.

24. Oliveira, S.; Rodenbusch, C.; Cé, M.; Rocha, S.; Canal, C. Evaluation of selective and non-selective enrichment PCR procedures for Salmonella detection. Lett. Appl. Microbiol. 2003, 36, 217-221. [CrossRef] [PubMed]

25. Akbarmehr, J.; Salehi, T.Z.; Brujeni, G. Identification of Salmonella isolated from poultry by MPCR technique and evaluation of their hsp groEL gene diversity based on the PCR-RFLP analysis. Afr. J. Microbiol. Res. 2010, 4, 1594-1598.

26. Liu, B.; Zhou, X.; Zhang, L.; Liu, W.; Dan, X.; Shi, C.; Shi, X. Development of a novel multiplex PCR assay for the identification of Salmonella enterica Typhimurium and Enteritidis. Food Control 2012, 27, 87-93. [CrossRef]

27. CLSI (Clinical and Laboratory Standards Institute). Standards for Antimicrobial Disk Susceptibility Test; Approved Standard; CLSI Document M02-A11; CLSI: Wayne, PA, USA, 2012.

28. Magiorakos, A.P.; Srinivasan, A.; Carey, R.B.; Carmeli, Y.; Falagas, M.E.; Giske, C.G.; Harbarth, S.; Hindler, J.F.; Kahlmeter, G.; Olsson-Liljequist, B.; et al. Multidrug-resistant, extensively drug-resistant and pandrug-resistant bacteria: An international expert proposal for interim standard definitions for acquired resistance. Clin. Microbiol. Infect. 2012, 18, 268-281. [CrossRef]

29. Krumperman, P.H. Multiple antibiotic resistance indexing of Escherichia coli to identify high-risk sources of fecal contamination of foods. Appl. Environ. Microbiol. 1983, 46, 165-170. [CrossRef]

30. Colom, K.; Pérez, J.; Alonso, R.; Fernández-Aranguiz, A.; Lariño, E.; Cisterna, R. Simple and reliable multiplex PCR assay for detection of bla TEM, bla SHV and bla OXA-1 genes in Enterobacteriaceae. FEMS Microbiol. Lett. 2003, 223, 147-151. [CrossRef]

31. Randall, L.; Cooles, S.; Osborn, M.; Piddock, L.; Woodward, M.J. Antibiotic resistance genes, integrons and multiple antibiotic resistance in thirty-five serotypes of Salmonella enterica isolated from humans and animals in the UK. J. Antimicrob. Chemother. 2004, 53, 208-216. [CrossRef] 
32. Sabarinath, A.; Tiwari, K.P.; Deallie, C.; Belot, G.; Vanpee, G.; Matthew, V.; Sharma, R.; Hariharan, H. Antimicrobial resistance and phylogenetic groups of commensal Escherichia Coli isolates from healthy pigs in Grenada. Webmed Cent. Vet. Med. 2011, 2, 1-10.

33. Mottaghizadeh, F.; Haeili, M.; Darban-Sarokhalil, D. Molecular epidemiology and nitrofurantoin resistance determinants from nitrofurantoin non-susceptible Escherichia coli isolated from urinary tract infections. J. Glob. Antimicrob. Resist. 2019, 21, 335-339. [CrossRef]

34. Rabie, G.; El-Abedeen, A.Z.; Bakry, A.A. Biological synthesis of silver nanoparticles using filamentous fungi. Nano Sci. Nano Technol. J. 2013, 7, 163-171.

35. El-Gazzar, N.S.; Rabie, G.H. Application of silver nanoparticles on Cephalosporium maydis in vitro and in vivo. Egypt. J. Microbiol. 2018, 53, 69-81.

36. White, T.J.; Bruns, T.; Lee, S.; Taylor, J. Amplification and direct sequencing of fungal ribosomal RNA genes for phylogenetics. PCR Protoc. A Guide Methods Appl. 1990, 18, 315-322.

37. DeAlba-Montero, I.; Guajardo-Pacheco, J.; Morales-Sánchez, E.; Araujo-Martínez, R.; Loredo-Becerra, G.; Martínez-Castañón, G.-A.; Ruiz, F.; Compeán Jasso, M. Antimicrobial properties of copper nanoparticles and amino acid chelated copper nanoparticles produced by using a soya extract. Bioinorg. Chem. Appl. 2017, 2017, 1064918. [CrossRef] [PubMed]

38. Bauer, A. Antibiotic susceptibility testing by a standardized single disc method. Am. J. Clin. Pathol. 1966, 45, 149-158. [CrossRef]

39. Krishnan, R.; Arumugam, V.; Vasaviah, S.K. The MIC and MBC of silver nanoparticles against Enterococcus faecalis-A facultative anaerobe. J. Nanomed. Nanotechnol. 2015, 6, 285.

40. Thatcher, F.S.; Clark, D.S. Micro-Organisms in Foods: Their Significance and Methods of Enumeration; University of Toronto Press: Toronto, ON, Canada, 1968.

41. Yuan, J.S.; Reed, A.; Chen, F.; Stewart, C.N. Statistical analysis of real-time PCR data. BMC Bioinform. 2006, 7, 85. [CrossRef]

42. Gu, Z.; Eils, R.; Schlesner, M. Complex heatmaps reveal patterns and correlations in multidimensional genomic data. Bioinformatics 2016, 32, 2847-2849. [CrossRef]

43. Kruskal, J.B. Multidimensional scaling by optimizing goodness of fit to a nonmetric hypothesis. Psychometrika 1964, $29,1-27$. [CrossRef]

44. Mughini-Gras, L.; Enserink, R.; Friesema, I.; Heck, M.; van Duynhoven, Y.; van Pelt, W. Risk factors for human salmonellosis originating from pigs, cattle, broiler chickens and egg laying hens: A combined case-control and source attribution analysis. PLoS ONE 2014, 9, e87933.

45. Elkenany, R.; Elsayed, M.M.; Zakaria, A.I.; El-sayed, S.A.-E.-S.; Rizk, M.A. Antimicrobial resistance profiles and virulence genotyping of Salmonella enterica serovars recovered from broiler chickens and chicken carcasses in Egypt. BMC Vet. Res. 2019, 15, 124. [CrossRef] [PubMed]

46. Rodríguez, R.; Fandiño, C.; Donado, P.; Guzmán, L.; Verjan, N. Characterization of Salmonella from commercial egg-laying hen farms in a central region of Colombia. Avian. Dis. 2015, 59, 57-63. [CrossRef]

47. Lamas, A.; Fernandez-No, I.; Miranda, J.; Vázquez, B.; Cepeda, A.; Franco, C. Prevalence, molecular characterization and antimicrobial resistance of Salmonella serovars isolated from northwestern Spanish broiler flocks (2011-2015). Poult. Sci. 2016, 95, 2097-2105. [CrossRef] [PubMed]

48. Ahmed, H.; Gharieb, R.M.; Mohamed, M.E.; Amin, M.A.; Mohamed, R.E. Bacteriological and molecular characterization of Salmonella species isolated from humans and chickens in Sharkia Governorate, Egypt. Zagazig Vet. J. 2017, 45, 48-61. [CrossRef]

49. Gharieb, R.M.; Tartor, Y.H.; Khedr, M.H. Non-Typhoidal Salmonella in poultry meat and diarrhoeic patients: Prevalence, antibiogram, virulotyping, molecular detection and sequencing of class I integrons in multidrug resistant strains. Gut Pathog. 2015, 7, 34. [CrossRef]

50. Zubair, A.I.; Al-Berfkani, M.I.; Issa, A.R. Prevalence of Salmonella species from poultry eggs of local stores in Duhok. Int. J. Res. Med. Sci. 2017, 5, 2468-2471. [CrossRef]

51. García, C.; Soriano, J.; Benítez, V.; Catalá-Gregori, P. Assessment of Salmonella spp. in feces, cloacal swabs, and eggs (eggshell and content separately) from a laying hen farm. Poult. Sci. 2011, 90, 1581-1585. [CrossRef]

52. Nascimento, V.; Cranstoun, S.; Solomon, S. Relationship between shell structure and movement of Salmonella enteritidis across the eggshell wall. Br. Poult. Sci. 1992, 33, 37-48. [CrossRef]

53. Borges, K.A.; Furian, T.Q.; Borsoi, A.; Moraes, H.L.; Salle, C.T.; Nascimento, V.P. Detection of virulence-associated genes in Salmonella Enteritidis isolates from chicken in South of Brazil. Pesqui. Vet. Bras. 2013, 33, 1416-1422. [CrossRef]

54. Singh, R.; Yadav, A.; Tripathi, V.; Singh, R. Antimicrobial resistance profile of Salmonella present in poultry and poultry environment in north India. Food Control 2013, 33, 545-548. [CrossRef]

55. Andoh, L.A.; Dalsgaard, A.; Obiri-Danso, K.; Newman, M.; Barco, L.; Olsen, J.E. Prevalence and antimicrobial resistance of Salmonella serovars isolated from poultry in Ghana. Epidemiol. Infect. 2016, 144, 3288-3299. [CrossRef] [PubMed]

56. Brown, K.; Uwiera, R.R.; Kalmokoff, M.L.; Brooks, S.P.; Inglis, G.D. Antimicrobial growth promoter use in livestock: A requirement to understand their modes of action to develop effective alternatives. Int. J. Antimicrob. Agents 2017, 49, 12-24. [CrossRef] [PubMed]

57. Abdeen, E.; Elmonir, W.; Suelam, I.; Mousa, W. Antibiogram and genetic diversity of Salmonella enterica with zoonotic potential isolated from morbid native chickens and pigeons in Egypt. J. Appl. Microbiol. 2018, 124, 1265-1273. [CrossRef]

58. Diab, M.S.; Zaki, R.S.; Ibrahim, N.A.; Abd El Hafez, M.S. Prevalence of Multidrug Resistance Non-Typhoidal Salmonellae Isolated from Layer Farms and Humans in Egypt. World Vet. J. 2019, 9, 280-288. [CrossRef] 
59. Sharma, J.; Kumar, D.; Hussain, S.; Pathak, A.; Shukla, M.; Kumar, V.P.; Anisha, P.; Rautela, R.; Upadhyay, A.; Singh, S. Prevalence, antimicrobial resistance and virulence genes characterization of nontyphoidal Salmonella isolated from retail chicken meat shops in Northern India. Food Control 2019, 102, 104-111. [CrossRef]

60. Miranda, J.; Guarddon, M.; Vázquez, B.; Fente, C.; Barros-Velázquez, J.; Cepeda, A.; Franco, C. Antimicrobial resistance in Enterobacteriaceae strains isolated from organic chicken, conventional chicken and conventional turkey meat: A comparative survey. Food Control 2008, 19, 412-416. [CrossRef]

61. Alali, W.Q.; Thakur, S.; Berghaus, R.D.; Martin, M.P.; Gebreyes, W.A. Prevalence and distribution of Salmonella in organic and conventional broiler poultry farms. Foodborne Pathog. Dis. 2010, 7, 1363-1371. [CrossRef]

62. Bai, L.; Lan, R.; Zhang, X.; Cui, S.; Xu, J.; Guo, Y.; Li, F.; Zhang, D. Prevalence of Salmonella isolates from chicken and pig slaughterhouses and emergence of ciprofloxacin and cefotaxime co-resistant S. enterica serovar Indiana in Henan, China. PLoS ONE 2015, 10, e0144532. [CrossRef]

63. Zhao, X.; Gao, Y.; Ye, C.; Yang, L.; Wang, T.; Chang, W. Prevalence and characteristics of Salmonella isolated from free-range chickens in Shandong Province, China. BioMed Res. Int. 2016, 2016, 8183931. [CrossRef]

64. Lekshmi, M.; Ammini, P.; Kumar, S.; Varela, M.F. The food production environment and the development of antimicrobial resistance in human pathogens of animal origin. Microorganisms 2017, 5, 11. [CrossRef] [PubMed]

65. Yang, B.; Qu, D.; Zhang, X.; Shen, J.; Cui, S.; Shi, Y.; Xi, M.; Sheng, M.; Zhi, S.; Meng, J. Prevalence and characterization of Salmonella serovars in retail meats of marketplace in Shaanxi, China. Int. J. Food Microbiol. 2010, 141, 63-72. [CrossRef] [PubMed]

66. Thung, T.Y.; Radu, S.; Mahyudin, N.A.; Rukayadi, Y.; Zakaria, Z.; Mazlan, N.; Tan, B.H.; Lee, E.; Yeoh, S.L.; Chin, Y.Z. Prevalence, virulence genes and antimicrobial resistance profiles of Salmonella serovars from retail beef in Selangor, Malaysia. Front. Microbiol. 2018, 8, 2697. [CrossRef]

67. El-Sharkawy, H.; Tahoun, A.; El-Gohary, A.E.-G.A.; El-Abasy, M.; El-Khayat, F.; Gillespie, T.; Kitade, Y.; Hafez, H.M.; Neubauer, H.; El-Adawy, H. Epidemiological, molecular characterization and antibiotic resistance of Salmonella enterica serovars isolated from chicken farms in Egypt. Gut Pathog. 2017, 9, 8. [CrossRef]

68. Abdel-Shafi, S.; Al-Mohammadi, A.-R.; Osman, A.; Enan, G.; Abdel-Hameid, S.; Sitohy, M. Characterization and Antibacterial Activity of 7S and 11S Globulins Isolated from Cowpea Seed Protein. Molecules 2019, 24, 1082. [CrossRef] [PubMed]

69. El-Gazzard, N.; Ismail, A. The potential use of Titanium, Silver and Selenium nanoparticles in controlling leaf blight of tomato caused by Alternaria alternata. Biocatal. Agric. Biotechnol. 2020, 27, 101708. [CrossRef]

70. Nakkala, J.R.; Mata, R.; Sadras, S.R. Green synthesized nano silver: Synthesis, physicochemical profiling, antibacterial, anticancer activities and biological in vivo toxicity. J. Colloid Interface Sci. 2017, 499, 33-45. [CrossRef] [PubMed]

71. Rai, M.; Yadav, A.; Gade, A. Silver nanoparticles as a new generation of antimicrobials. Biotechnol. Adv. 2009, 27, 76-83. [CrossRef] [PubMed]

72. Shaligram, N.S.; Bule, M.; Bhambure, R.; Singhal, R.S.; Singh, S.K.; Szakacs, G.; Pandey, A. Biosynthesis of silver nanoparticles using aqueous extract from the compactin producing fungal strain. Process Biochem. 2009, 44, 939-943. [CrossRef]

73. Cavassin, E.D.; de Figueiredo, L.F.P.; Otoch, J.P.; Seckler, M.M.; de Oliveira, R.A.; Franco, F.F.; Marangoni, V.S.; Zucolotto, V.; Levin, A.S.S.; Costa, S.F. Comparison of methods to detect the in vitro activity of silver nanoparticles (AgNP) against multidrug resistant bacteria. J. Nanobiotechnology 2015, 13, 64. [CrossRef]

74. Loo, Y.Y.; Rukayadi, Y.; Nor-Khaizura, M.-A.-R.; Kuan, C.H.; Chieng, B.W.; Nishibuchi, M.; Radu, S. In vitro antimicrobial activity of green synthesized silver nanoparticles against selected gram-negative foodborne pathogens. Front. Microbiol. 2018, 9, 1555. [CrossRef] [PubMed]

75. Sondi, I.; Siiman, O.; Matijević, E. Synthesis of CdSe nanoparticles in the presence of aminodextran as stabilizing and capping agent. J. Colloid Interface Sci. 2004, 275, 503-507. [CrossRef] [PubMed]

76. Tanhaeian, A.; Ahmadi, F.S. Inhibitory effect of biologically synthesized silver nanoparticle on growth and virulence of $E$. coli. Zahedan J. Res. Med. Sci. 2018, 20, e10269. 